TECTONICS, VOL. 5, NO. 7, PAGES 1145-1160, DECEMBER 1986

\section{TECTONICALLY CONTROLLED ORIGIN OF THREE UNUSUAL ROCK SUITES IN THE WOODLARK BASIN}

\author{
Dallas Abbott and Martin Fisk \\ College of Oceanography, Oregon State University, \\ Corvallis, Oregon
}

that this formerly subducting plate is still cold enough to retain volatiles and to remain seismically active. As the old plate loses volatiles, they rise into the mantle convection cell which feeds the Woodlark basin ridge crest. Because ridge subduction increases the likelihood of ophiolite obduction, these observations and explanations of Woodlark basin tectonics are potentially important for ophiolites.

\section{INTRODUCTION}

The Woodlark Basin, located in the southwest Pacific Ocean east of Papua New Guinea, contains an actively spreading ridge, that is being subducted beneath the New Georgia island arc to the northeast (Figures 1 and 2). A second lithospheric slab, a relic from a previous period of southward subduction of the Pacific plate, is emplaced beneath the island arc from the north.

Although oceanic crust further than $150 \mathrm{~km}$ from the subduction zone is normal mid-ocean ridge basalt (MORB), the other rocks from the Woodlark basin spreading center belong to three different suites: (1) arclike rocks, basalts through dacites with a high content of arclike component; (2) high-Mg andesites, andesites with a high magnesium content, and (3) NaTi basalts, basalts with a high sodium and titanium content [Perfit et al., 1986]. The high-Mg andesites and $\mathrm{NaTi}$ basalts formed at transform zones within $50 \mathrm{~km}$ of the trench. The arclike rocks were generated at ridge crests within $150 \mathrm{~km}$ of the trench [Taylor and Exon, 1986].

The three spatially restricted suites are all unusual in their tectonic location. High-Mg andesites have been previously found in island arc and forearc regions [Johnson et al., 1983; Reagan and Meijer,
Paper number 6T0474.

0278-7407/86/006T-0474\$10.00 


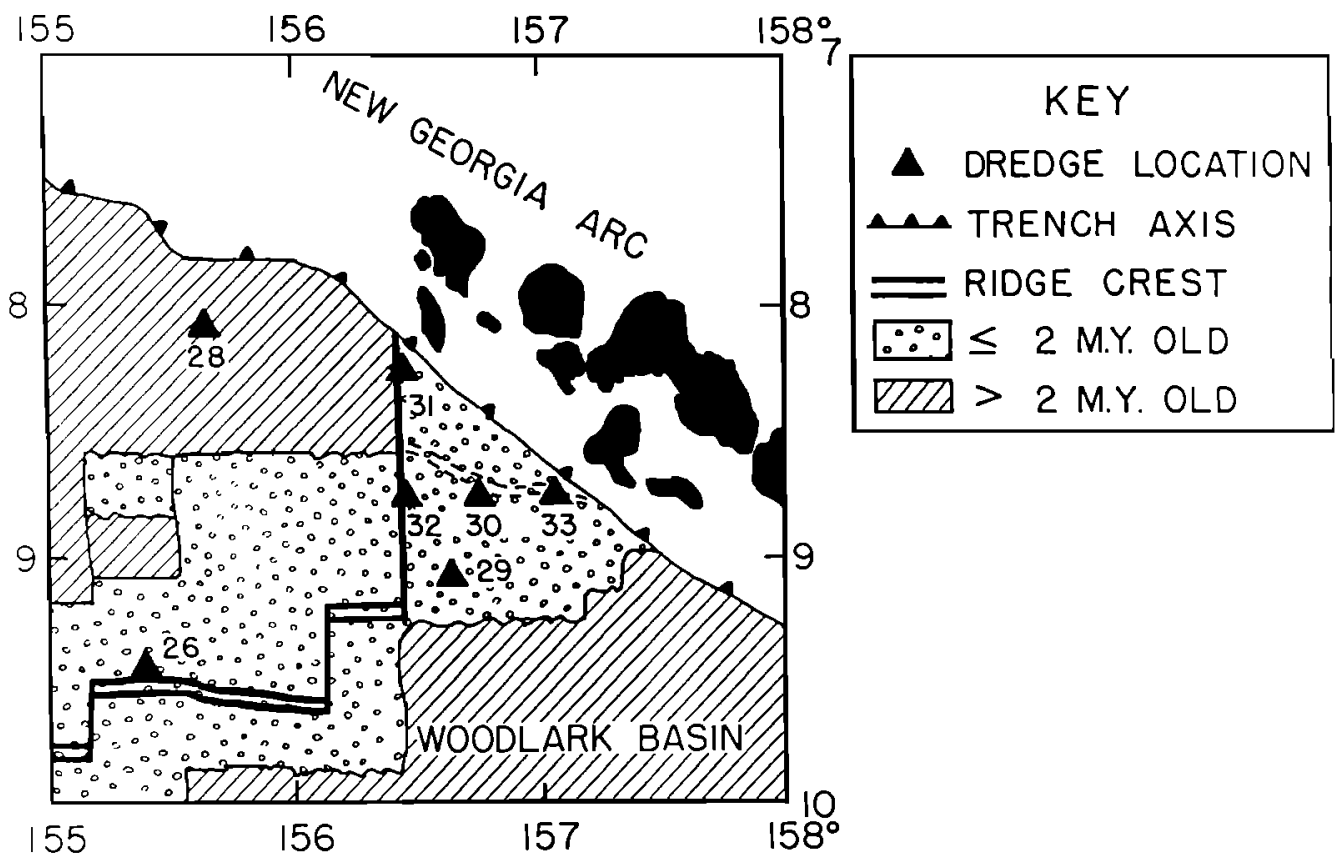

Fig. 1. The Woodlark basin: an area where lithospheric flexure may be affecting hydrothermal and volcanic activity (map after Taylor and Exon [1986]). The spreading center marked by double dashed lines (Ghizo ridge) is erupting island arc-type tholeiites, dacites, and andesites and is within the flexural bulge. Triangles are dredge haul locations. Dredges 31 and 32 are on the Simbo fracture zone and transform fault. Dredge 31 recovered high-Mg andesites and arclike rocks. Dredge 32 recovered NaTi basalts and arclike rocks. Dredge 26 recovered normal MORBs [after Taylor, 1986].

1984], but have never before been found on a transform fault. NaTi basalts have been found at five other sites, four of which are far from subduction zones [CAYTROUGH, 1979; Schilling et al., 1983; Cousens et al., 1984; W.G.Melson and T. O'Hearn, unpublished compilation of glass analyses of MORB, 1985]. All four of these sites are (or were) ridge segments bracketed at both ends by relatively old (10-30 m.y.) oceanic lithosphere. The NaTi basalts from the Woodlark basin erupted along a transform fault with an age contrast of only 2.6 m.y., much younger than in the other locations. Finally, the arclike rocks are commonly restricted to back-arc basins and island arcs, and the Woodlark basin is neither.

The origin of these rocks is relevant not only in the context of Woordlark basin petrology, but also to the much more general concern of whether terrestrial ophiolites really represent typical oceanic crustal rocks [Miyashiro, 1973; Moores and Jackson, 1974; Moores et al., 1984]. Ridge subduction, such as is occurring in the Woodlark basin, may increase the chances of ophiolite emplacement [Moores et al., 1984]. Consequently, there may be petrologic and chemical similarities between ophiolites and the unusual Woodlark basin rocks.
The factors which distinguish the Woodlark basin from other marginal basins are the subduction of very young oceanic crust (0-5 m.y.), a rapid convergence rate $(>10 \mathrm{~cm} / \mathrm{yr})$, and a polarity reversal of subduction (late Miocene) [Coleman and Kroenke, 1981; Weissel et al., 1982; Taylor, 1986; Figure 2]. The presence of ridge subduction, the rapid convergence rate, and the spatial restriction of the different rock types implies that the unusual volcanic character of the Woodlark basin may be caused by tectonic processes. Therefore, we examined two processes which could restrict unusual rock types to the vicinity of the trench: (1) unusually strong cooling of the lithosphere by hydrothermal circulation, which could be responsible for the high-Mg andesites and $\mathrm{NaTi}$ basalts, and (2) volatile loss from the relict subducting plate, which could be responsible for the arclike rocks.

\section{LITHOSPHERIC COOLING AND PLATE FLEXURE}

The oceanic crust created at mid-ocean ridges is cooled by a combination of conduction and 


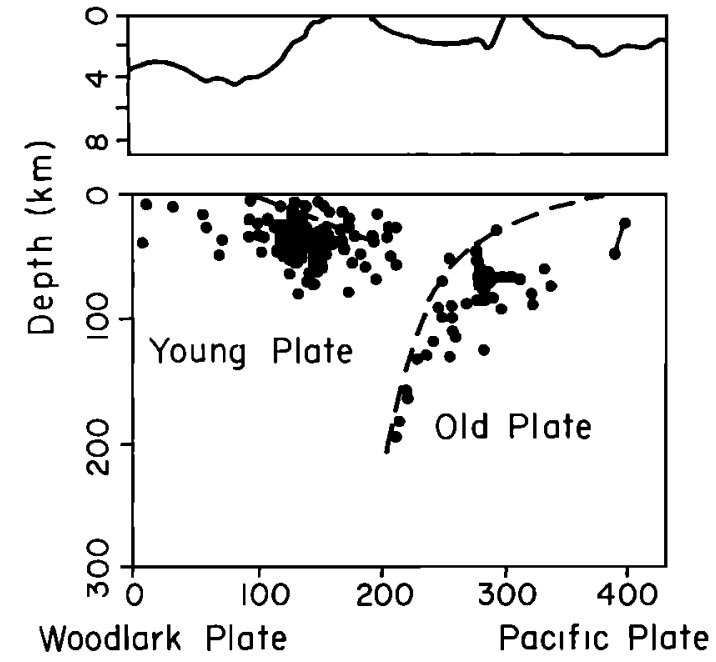

Fig. 2. Seismicity beneath the New Georgia island arc [after Cooper and Taylor, 1985]. Both the old, previously subducting Pacific plate (right) and the presently subducting Woodlark basin plate (left) are clearly visible. The seismic data imply that the older subducting plate is intact and has not broken apart.

convection. The relative importance of conduction and convection depends primarily on the bulk permeability of the crust-sediment system. Because marine sediments are usually several orders of magnitude less permeable than basalt [Abbott et al., 1981; Anderson et al., 1985], the deposition of 200-300 meters of sediment on top of the basalt basement normally causes crustal cooling to be dominated by conduction rather than convection [Anderson et al., 1979]. However, the intensity of hydrothermal convection increases with increasing total available heat, topographic roughness, and system permeability [Stefanson, 1983; Fehn et al., 1983]. Thus, changing any one of these variables can change the amount of convective hydrothermal cooling at mid-ocean ridges.

Fracturing increases the number of interconnected voids within oceanic crust and thus increases the permeability of the oceanic crust. The increased permeability stimulates hydrothermal circulation, especially in the lower layers of the oceanic crust. The primary cause of these cracks is thought to be tensile thermoelastic stresses induced by the cooling and contraction of aging oceanic crust [Lister, 1974; Bratt et al., 1985]. Laboratory experiments on small mineral samples indicate that cracks can propagate at deviatoric stresses of 500 bars or greater [Martin, 1972]. However, the strength of the oceanic crust is probably less than 500 bars, since any sufficiently large piece of material will contain many preexisting flaws and zones of weakness. Bodine et al. [1981] modeled the strength of the crust under tension as increasing from near zero at the surface to higher values at depth at a rate of $0.222 \mathrm{kbar} / \mathrm{km}$. We assume this model in the discussion to follow.

Lithospheric flexure is one source of tensile stress. Lithospheric plates bend as they enter subduction zones. This flexure produces large tensional stresses in the upper half of the subducting oceanic plate (Figures 3 and 4). These high tensile stresses can cause new cracks to form on the surface of the flexural bulge. These cracks will propagate downward until the breaking strength of the rock exceeds the tensile stresses induced by flexure (Table 1). These new cracks add to cracks caused by thermoelastic stresses.

Increased hydrothermal circulation produces large chemical and thermal changes within the oceanic crust. If flexurally induced cracking and faulting increases the permeability or the topographic roughness of an unsealed plate, hydrothermal circulation will intensify. Although oceanic crust as old as $80 \mathrm{~m} . \mathrm{y}$. is sometimes hydrothermally active [Embley et al., 1983], these older, hydrothermally active areas are located in oceanic areas with unusually low sedimentation rates. Because sedimentation rates near trenches are usually quite high, the sediment cover on most subducting oceanic crust reaches a thickness of 200-300 meters when the subducting plate is only 0-20 m.y. old. The subducting plate in the Woodlark basin is 0-5 m.y. old and is covered by less than 200 meters of sediment; thus hydrothermal circulation and consequent lithospheric cooling should be intensified by flexurally induced cracking.

\section{EVIDENCE FOR INCREASED CRACKING DUE TO LITHOSPHERIC FLEXURE}

Three observations indicate that new cracks form at flexural bulges: normal fault earthquakes, new fault blocks, and pore water helium anomalies. Many trenches have reactivated fault blocks on the flexurally formed seaward trench slope [Schweller and Kulm, 1978; Watts et al., 1980]. In the Peru-Chile trench at $22^{\circ}-27^{\circ} \mathrm{S}$ and in the Guatemala trench at $12^{\circ}-14^{\circ} \mathrm{N}$, some of these fault blocks are aligned parallel to the trend of the trench, rather than perpendicular to the original spreading direction [Von Huene and Aubouin, 1982; Schweller et al, 1981, Figure 6]. These observations imply that lithosphere flexure can cause the formation of new faults and that the deviatoric stresses in the upper part of the flexural bulge exceed the tensile strength of the rock. Because cracks propagate at roughly half the stress that is required to break the rock [Verhoogen et al., 1970], new cracks will form at greater depths than new faults.

The ${ }^{3} \mathrm{He} /{ }^{4} \mathrm{He}$ ratio of gas contained in mid-ocean ridge rocks derived from the mantle source of normal MORB is $\sim 1.15 \times 10^{-5}$ [Lupton and Craig, 1975; R. Barnes, unpublished manuscript, 1986]. When the rocks are cracked, juvenile helium is 


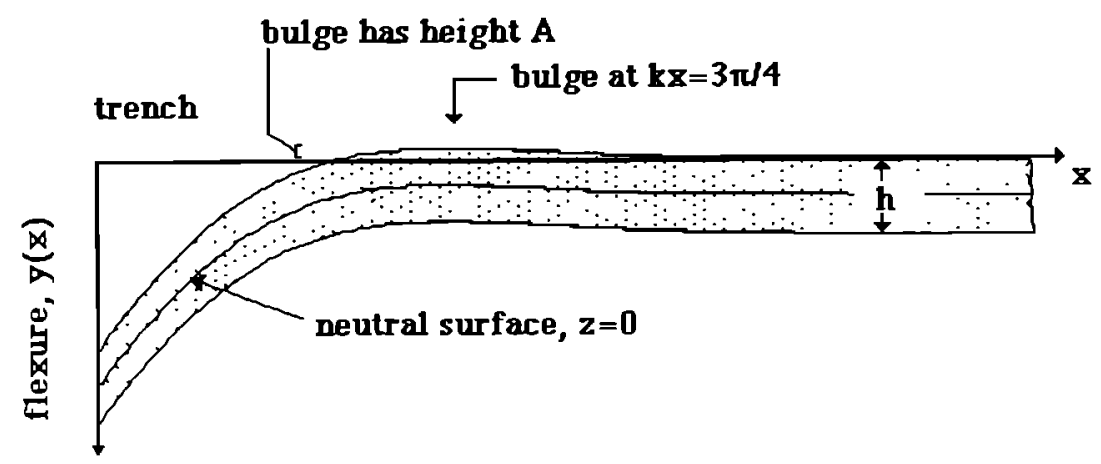

Fig. 3. Diagram of lithospheric flexure at a trench (not to scale): $h$, elastic thickness; $x$, horizontal distance from the load; $z$, distance above or below the neutral surface; $y(x)$, flexure of the plate; $A$, maximum height of the bulge above the surface of zero deflection (measured from the seaward side of the plate). The bulge has its maximum height at $\mathrm{kx}=3 \pi / 4$. The maximum stress is at $\mathrm{kx}=\pi / 4$. The upper half of the plate is in tension; the lower half of the plate is in compression.

released. Because most seawater has a low concentration of $\mathrm{He}$ relative to the rock and has the atmospheric ${ }^{3} \mathrm{He} /{ }^{4} \mathrm{He}$ ratio of $1.4 \times 10^{-6}$ [Lupton et al., 1980], the release of helium by the cracking of newly emplaced rock causes anomalies in the ${ }^{3} \mathrm{He} / 4 \mathrm{He}$ ratio of pore fluids emitted at hydrothermal vents at mid-ocean ridges. Fracturing of older, previously uncracked oceanic lithosphere will also release juvenile helium gas into the surrounding water. The only Deep Sea Drilling Project (DSDP) site drilled on top of a flexural bulge, site 436 , located on 110-m.y.-old lithosphere entering the Japan trench, has a ${ }^{3} \mathrm{He} /{ }^{4} \mathrm{He}$ ratio of $4.40 \times 10^{-6}$ in the pore water [R. Barnes, unpublished manuscript, 1986]. To produce this ratio, $10 \%$ of the pore water helium must come from newly cracked rocks. As the helium diffuses slowly through the sediments, the ${ }^{3} \mathrm{He} /{ }^{4} \mathrm{He}$ ratio of the pore water decreases. Consequently, $100 \%$ of the pore water helium at

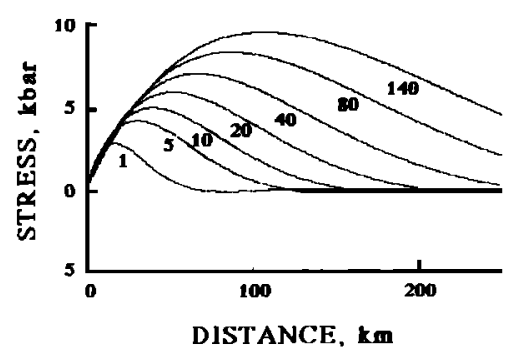

Fig. 4. The tensile stress at the top of the plate (z $=1 / 2 \mathrm{~h}$ ) versus distance from the beginning of the trench within lithospheric plates of different ages (in millions of years). Note that the maximum tensile stress exceeds the breaking strength of the rock (1 $\mathrm{kbar}$ ) and the crack propagation stress even in the youngest subducting plates. See appendix for derivation of the figure. depth could come from newly cracked rock [R. Barnes, unpublished manuscript, 1986].

\section{TENSILE STRESS CAUSED BY LITHOSPHERIC FLEXURE}

Thicker plates are more difficult to bend, and consequently, stresses and cracking induced by flexural bending of the plate are proportional to the thickness of the plate. Because plates increase in thickness as they age, maximum flexural tensile stresses increase with increasing age of the plate. These flexural tensile stresses are concentrated in the part of the plate which behaves elastically. The mechanical thickness of the plate is the thickness of the layer that breaks rather than flows under the influence of large flexural bending stresses, and is approximately given by the depth to the $600^{\circ} \mathrm{C}$ isotherm [McNutt, 1984]. Mechanical thickness should not be confused with the plate's thermal thickness, which is roughly equal to the depth to the $1300^{\circ} \mathrm{C}$ isotherm [Parsons and Sclater, 1977]. If tensional cracks and deep water circulation are present, the convective transfer of heat will increase the depth to the $600{ }^{\circ} \mathrm{C}$ isotherm and will consequently increase the mechanical thickness.

The portion of the plate that has increased surface tensile stresses induced by flexure is called the flexural bulge. Our calculations (see appendix for details) of the tensile stress at the top of the plate within the flexural bulge indicate that stresses will locally exceed the strength of the rock (Figure 4). The depth of cracking varies with plate age. For a 5-m.y.-old plate, cracks may extend to $3.7 \mathrm{~km}$ depth near the flexural bulge (Table 1). Figure 5 shows the depth of cracking and consequent hydrothermal alteration which can be produced by lithospheric flexure. On plates older than 20 m.y., this depth is greater than the 4- to 8-km depth of hydrothermal 
TABLE 1. Elastic Half-Thickness, Maximum Tensional Stress at the Top of the Plate near the Flexural Bulge, and Maximum Depth of Flexure-Induced Cracking, of the Oceanic Lithosphere as a Function of Plate Age*

\begin{tabular}{cccc}
\hline Plate Age, m.y. & Elastic Half-Thickness, $\mathrm{km}$ & Maximum Stress, kbar & Depth, $\mathrm{km}$ \\
\hline 1 & & & \\
5 & 2.1 & 3.1 & 3.8 \\
10 & 4.6 & 4.2 & 5.1 \\
20 & 6.6 & 5.2 & 6.9 \\
40 & 9.3 & 6.2 & 9.2 \\
80 & 13.1 & 7.2 & 12.3 \\
140 & 18.6 & 8.6 & 15.6 \\
\hline
\end{tabular}

*The plate is assumed to be conductively cooled.

alteration inferred from marine seismic studies [Lewis, 1978; Abbott and Lyle, 1984] and from ophiolites [Gregory and Taylor, 1981; Cocker et al., 1982]. This implies that the cracking of the oceanic crust in the vicinity of flexural bulges will very quickly exceed the normal depth of the hydrothermal cracking and will result in the release of juvenile $3_{\mathrm{He}}$. Our calculations are therefore consistent with the observation of pore water helium anomalies in the sediment overlying the flexural bulge next to the Japan trench.

\section{CALCULATION OF THE DEPTH OF HYDROTHERMAL CIRCULATION}

Hydrothermal convection lowers the temperatures in the upper part of the plate (Figure 6). Because the mechanical thickness of the plate is determined by the depth to the $600^{\circ} \mathrm{C}$ isotherm, these lower temperatures will also increase the thickness of the

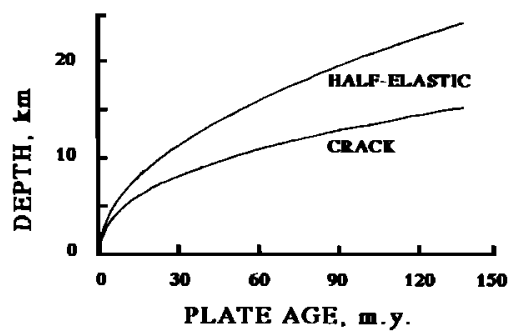

Fig. 5. Elastic half-thickness of a conductively cooled plate and cracked thickness of the same plate at the apex of the flexural bulge versus age of the plate in millions of years. The cracked layer has flexurally generated tensile stresses which exceed the breaking strength of the rock. The dashed line indicates the approximate increase in elastic half-thickness of the plate caused by heat removal during hydrothermal circulation. See appendix for derivation of the figure. layer which has tensile stresses (Figure 5). Tensile stresses will occur in the upper half of this layer, which is bounded roughly by the $300^{\circ} \mathrm{C}$ isotherm. Although we have no data on the temperatures within ridge crest crust affected by flexure, Fehn et al. [1983] modeled the intensity of hydrothermal circulation at the Costa Rica rift by using crustal models with different rates of exponential decrease of permeability with increasing depth. Subsequent in situ measurements in the same area found that the permeability of the oceanic crust does decrease exponentially with increasing depth [Anderson et al., 1985]. Fehn et al. [1983] found that a change in thickness from $\sim 2.5 \mathrm{~km}$ to $\sim 4.2 \mathrm{~km}$ of the layer with a high enough permeability to support active hydrothermal circulation changed the ratio between minimum and maximum values of heat flow in one off-ridge convection cell from about $1: 2$ to about $1: 8$ (Figure 7). The model with a maximum depth of circulation of $\sim 4.2 \mathrm{~km}$ produced the best fit to surface measurements of heat flow. Subsequent, independent observations of the heat flow in this area indicate a maximum depth of hydrothermal cooling of 4-6 km [Hobart et al., 1985]. If we use the isotherms in Fehn's models, the depth to the $300^{\circ} \mathrm{C}$ isotherm on crust less than 1 m.y. old with active hydrothermal circulation is at least $3 \mathrm{~km}$, equivalent to the thickness of the layer with tensile flexural stresses within a conductively cooled 5-m.y.-old plate (Figure 5). The maximum depth of significant hydrothermal circulation is shown by the streamlines to be $4.2 \mathrm{~km}$. Because hydrothermal cracking is caused by the temperature contrast between the water and the surrounding rock [Lister, 1983], this greater depth is actually a better estimate of the maximum depth of cracking.

We can estimate the effect of flexure on the hydrothermal circulation by noting that lithospheric flexure roughly doubles the number of large faults on the trench wall. Other factors being equal, a doubling of surface faults would quadruple the average surface permeability of the oceanic crust and 


\section{Temperature}
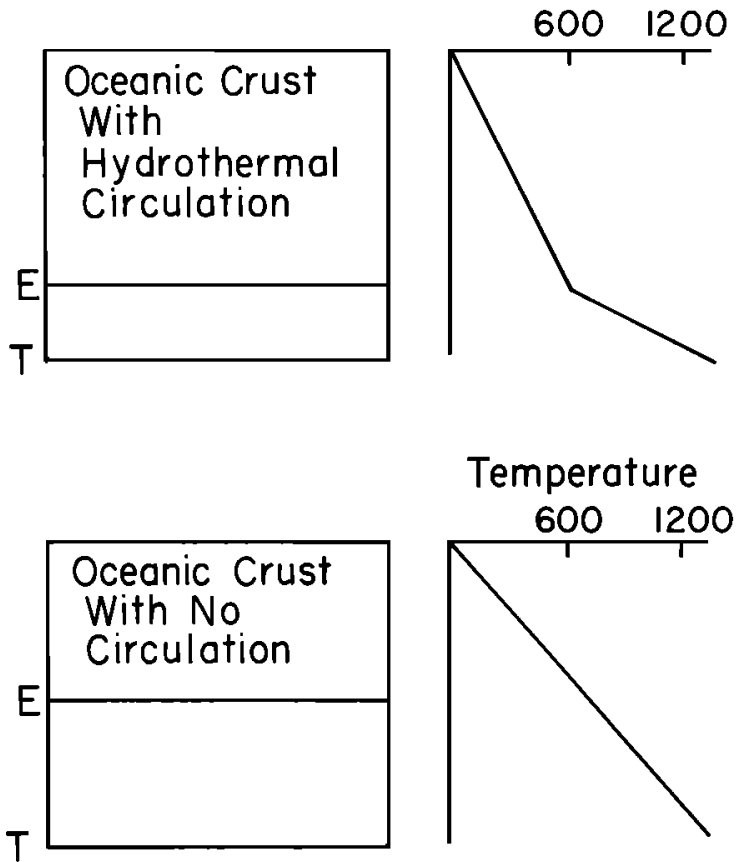

Fig. 6. Schematic cartoon showing the change in the thermal profile (right) and consequent increase in the elastic thickness, E, of young lithosphere (left) as a result of hydrothermal circulation. Circulating fluids are estimated to have a maximum temperature of $400^{\circ}-500^{\circ} \mathrm{C}$. In this cartoon, the total thermal thickness, $T$, does not change. If flexurally induced cooling is profound, the thermal thickness will also increase.

would double the maximum depth of crack penetration [Lister, 1983]. This, in turn, would roughly double the maximum depth of hydrothermal circulation and alteration to $8.4 \mathrm{~km}$ (Figure 5).

\section{TRANSFORM FAULTS AS A SECONDARY CAUSE OF HIGH PERMEABILITY}

In addition to flexurally induced tensile stresses, transform faults can cause local increases in tensile stress which depend upon the orientation of the transform within the regional stress field. If the regional tensile stress axis is parallel to the orientation of the transform, the maximum tensile stress near the transform will be $50 \%$ greater than the regional stress [Fujita and Sleep, 1978]. However, if the transform fault is oriented at an angle of $30^{\circ}$ to the regional tensile stress, the maximum tensile stress near the transform will be twice the regional stress [Fujita and Sleep, 1978]. The regional deviatoric stress fields within large plates have a maximum magnitude of 100-200 bars [Richardson et al., 1979]. This implies that maximum deviatoric stresses near transform faults could be as high as $200-400$ bars: a significant fraction of the total stress required to propagate cracks.

Because of the small size of the plate, the regional stress field in the Woodlark basin has not been included in global solutions of intraplate stress [Richardson et al., 1979]. These global solutions indicate that slab pull and ridge push contribute significantly to intraplate stresses and that slab pull is about 2-3 times stronger than ridge push.

Consequently, the regional axis of tensional stress within the rapidly converging Woodlark basin plate is most likely within $30^{\circ}$ of the trend of the Simbo transform fault. This orientation of the regional stress field near the transform trace would cause local tensile stresses that exceed the regional tensional stresses by as much as $50-100 \%$ [Fujita and Sleep, 1978]. Therefore, tensional stresses along the Simbo transform fault will have three additive components: the first induced by thermoelastic stresses, the second by lithospheric flexure, and the third by the transform orientation.

A ridge crest or transform located on a flexural bulge should have an increased depth of hydrothermal circulation and increased cooling of the crust. The cool crust would result in short-lived crustal magma chambers, and consequently, any steady state magma chambers would lie within the mantle. Deep magma chambers may occur along

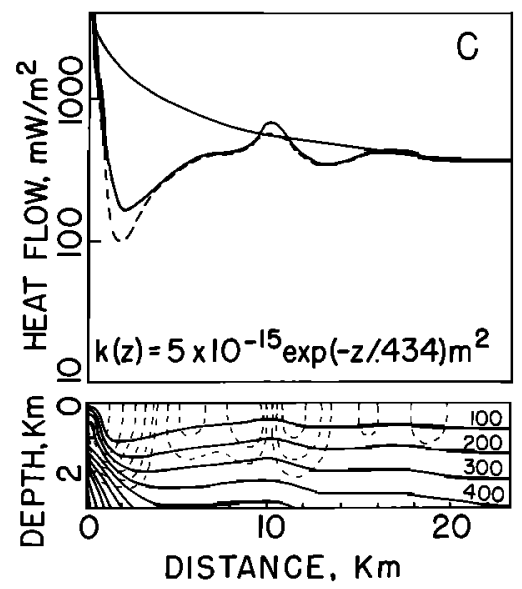

Fig. 7a. Top: Calculated heat flow versus distance from the ridge crest on a ridge with active hydrothermal convection. Solid lines: total heat flow. Dashed lines: conductive heat flow. Bottom: Streamlines of water flow (dashed lines) and isotherms (solid lines) versus distance from the ridge crest. Streamlines are unevenly spaced to better delineate areas of weak circulation. The function in the middle of the figure is the permeability, $\mathrm{k}$, in $\mathrm{m}^{2}$, versus depth, $z$, in the oceanic crust (in meters) [after Fehn et al., 1983]. 

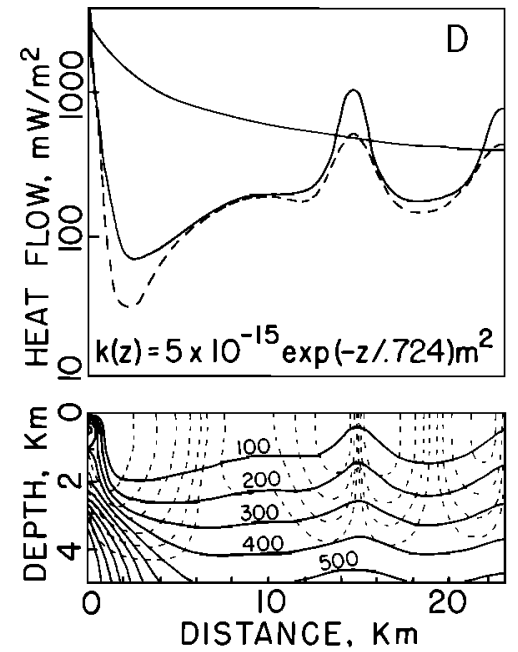

Fig. 7b. Same as Figure 7a, except for different permeability versus depth function. This model provides the best fit to heat flow measurements from the Costa Rica rift, an area of normal, unflexed oceanic crust [Fehn et al., 1983].

the Simbo transform where it crosses the flexural bulge (station 31, Figure 1). Recent volcanism on the Simbo transform occurs at two locations: near the ridge-transform intersection and at the Simbo volcano. This "leaky" behavior implies that the Simbo transform is not likely to have unusually thin crust, which could also produce a subcrustal magma chamber. Simbo volcano has been characterized as a forearc volcano, but the locations of deep earthquakes indicate that it is seaward of the trench [Cooper and Taylor, 1985]. As discussed earlier, the Simbo transform is in the proper orientation to magnify the regional tensile stresses induced by subduction.

\section{A DEEPER MAGMA CHAMBER AND THE FORMATION OF HIGH-Mg ANDESITES}

Fisk [1986] found that the interaction of n-type MORB and harzburgite at pressures of less than 10 $\mathrm{kbar}$ can produce high- $\mathrm{Mg}$ andesites [Johnson et al., 1986]. He infers that a subcrustal magma chamber can result in the generation of high-Mg andesites with boninitic affinities. High-Mg andesites with alkali enrichments similar to the experimentally produced andesites were found in a dredge haul northwest of the Simbo volcano in the Woodlark basin [Johnson et al., 1986]. In addition, comparison of experimentally produced andesites [Fisk, 1986] with naturally occurring oceanic andesites (Figure 8) shows that there are major element chemical similarities. Consequently, the Woodlark basin high-Mg andesites could have formed in a subcrustal magma chamber produced by increased hydrothermal cooling along the Simbo transform fault.

The other known occurrences of high-Mg andesites in arc volcanos support the idea that a magma chamber in contact with harzburgite can produce high-Mg andesites. Many island arcs and most continental arcs have crustal thicknesses in excess of $30 \mathrm{~km}$ [Gill, 1981]. In those arcs, magma chambers at less than $30 \mathrm{~km}$ would not bring basaltic magma into contact with harzburgite, and high- $\mathrm{Mg}$ andesites could not form by the mechanism proposed by Fisk [1986]. The two arcs with documented occurrences of high-Mg andesites (boninites), the Izu-Bonin arc [Hickey and Frey, 1982] and the New Britain arc [Johnson et al., 1983], have crustal thicknesses of $12-15 \mathrm{~km}$ and $20-30 \mathrm{~km}$, respectively [Gill, 1981].

Consequently, both of these arcs have locations where basaltic magma could equilibrate with harzburgite at pressures of less than $10 \mathrm{kbar}$.

\section{ORIGIN OF NaTi BASALTS}

Dredge haul 32 (Figure 1) sampled volcanic rocks formed at the intersection of the Simbo transform with the Woodlark basin spreading center, about $33 \mathrm{~km}$ from the trench. The flexural bulge produced by a 1 - to $2-\mathrm{m}$.y. old subducting plate is $50-60 \mathrm{~km}$ wide (Figure 3); thus the Simbo ridge-transform intersection is within the flexural bulge. This dredge recovered rocks with an unusual composition: over $4 \% \mathrm{Na}_{2} \mathrm{O}$, over $1.5 \% \mathrm{TiO}_{2}$, and less than $0.3 \% \mathrm{~K}_{2} \mathrm{O}$. Perfit et al. [1986] have termed these rocks NaTi basalts. We use a less restrictive definition for NaTi basalt of over $3.4 \%$ $\mathrm{Na}_{2} \mathrm{O}$, over $1.5 \% \mathrm{TiO}_{2}$, and less than $0.5 \% \mathrm{~K}_{2} 0$. The NaTi basalt must also have a Mg number indicating that it is not extensively fractionated and a low (less than $1 \%$ ) water content. Based on this definition, all of the basalt glasses dredged from the Cayman spreading center in the Caribbean are NaTi basalts [CAYTROUGH, 1979]. The Cayman spreading center is $110 \mathrm{~km}$ long and is bounded by two transforms over $1000 \mathrm{~km}$ long. At the ridge-transform intersections, each of these transforms juxtaposes new oceanic lithosphere against 34-m.y.-old lithosphere, producing age offsets of 34 m.y. [Fox and Gallo, 1984]. Because the Cayman ridge is relatively short, much or all of the ridge crest will "see" the thermal effects of the two bounding transform faults. The old oceanic lithosphere on the other side of the transform faults could indirectly produce rapid cooling of any shallow magma chambers as well as cooling of the local asthenosphere.

Enhanced crustal cooling is also associated with the unusual basalt glasses from the $40-\mathrm{km}$-long ridge segment in the Charlie Gibbs fracture zone (Figure 9). The age offsets of the two adjoining transform segments are 16 m.y. and 10 m.y. [Searle, 1981]. 


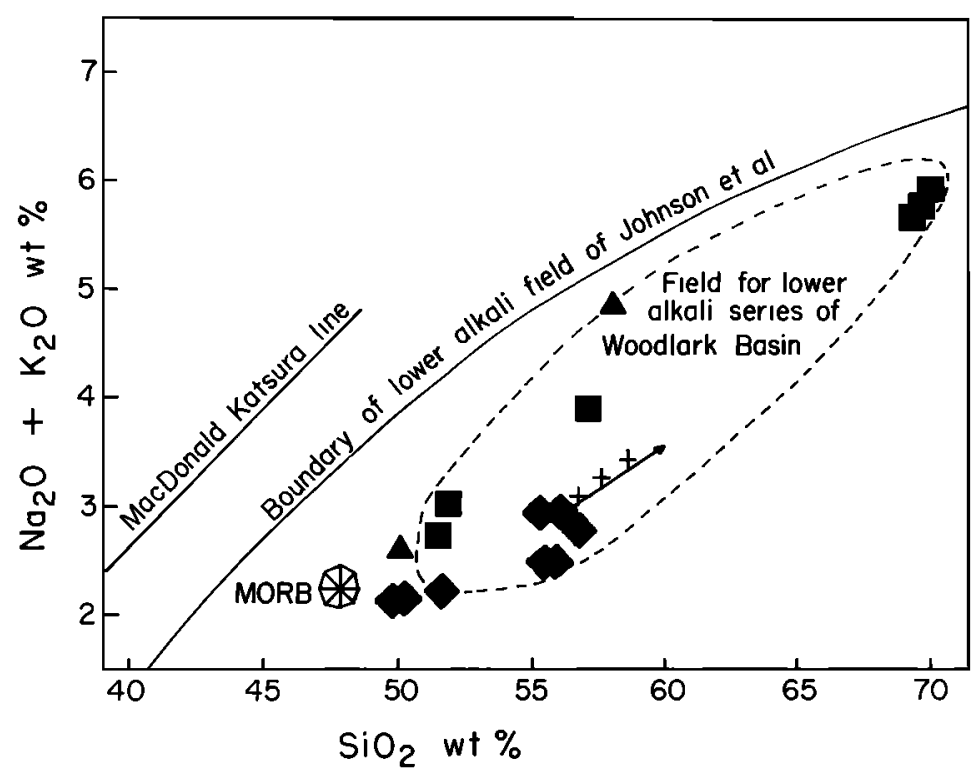

Fig. 8. Alkali-silica diagram for oceanic andesites and experimentally synthesized high-magnesium andesites. Triangles, Hart [1971]; squares, Byerly et al. [1976]; diamonds, experimentally produced liquids at $1250^{\circ} \mathrm{C}$; starred hexagon (MORB), which was the starting basalt composition in experiments, Fisk [1986]. Field for low silica andesites of Johnson et al. [1986] is shown. Fractional crystallization of olivine alone from the experimental andesite produces the silica and alkali enrichment shown by the line of crosses.

The three glass samples from the Charlie Gibbs ridge segment have $3.4-3.7 \% \mathrm{Na}_{2} \mathrm{O}, 1.6-2.0 \%$ $\mathrm{TiO}_{2}$, and $0.3-0.5 \% \mathrm{~K}_{2} \mathrm{O}$ [Schilling et al., 1983]. The water contents, which range from 0.1 to $0.6 \%$, are too low for the samples to have been extensively altered. The samples also have $\mathrm{Mg}$ numbers from 57 to 63 , and thus could not have been derived by fractionation. Consequently, two of the documented occurrences of NaTi basalts are from small ridge segments sandwiched between two long transform faults. In addition to the cooling effects caused by the long age offsets, the high topographic relief of long age offset transforms [Fox and Gallo, 1984] will also increase the intensity of hydrothermal circulation [Stefanson, 1983] and hence the efficiency of cooling of the oceanic lithosphere.

Another nonsubduction zone area where $\mathrm{NaTi}$ basalts have been found is at two topographic steps on the Southwest Indian ridge where the triple junction has been migrating eastward in successive ridge jumps. The large topographic steps [Anderson et al., 1977] and anomalously great depths [Sclater et al., 1981] observed at the boundary with the Antarctic plate on this part of the ridge crest are evidence that such ridge jumps have occurred. NaTi basalt glass $(8.5 \% \mathrm{FeO}, 7.6 \% \mathrm{MgO}, 4.2 \%$ $\mathrm{Na}_{2} \mathrm{O}, 0.2 \% \mathrm{~K}_{2} \mathrm{O}, 1.7 \% \mathrm{TiO}_{2}$ ) [W.G. Melson and T. O' Hearn, unpublished compilation of glass analyses of MORB, 1985] occurs at $28.85^{\circ} \mathrm{S}$, $61.92^{\circ} \mathrm{E}$, in an area where triple junction migration and a ridge jump have juxtaposed crust of about anomaly 19 and anomaly 8 ages [Sclater et al., 1981]. The jumping SW Indian ridge segment was thus thermally equivalent to a short ridge segment sandwiched between two pieces of 19-m.y.-old oceanic lithosphere. NaTi basalt glass $(8.5 \% \mathrm{FeO}$, $7.6 \% \mathrm{MgO}, 3.7 \% \mathrm{Na}_{2} \mathrm{O}, 0.2 \% \mathrm{~K}_{2} 0$, and $1.5 \%$ $\mathrm{TiO}_{2}$ ) [W.G. Melson and T. O' Hearn, unpublished compilation of glass analyses of MORB, 1985] also occurs at $26.62^{\circ} \mathrm{S}, 67.53^{\circ} \mathrm{E}$, where the triple junction migration boundary lies between crust of anomaly 7 and 5 age [Sclater et al., 1981]. This location was thermally equivalent to a small ridge segment between two transforms with age offsets of $18 \mathrm{~m} . \mathrm{y}$. Thus, the NaTi basalts on the Southwest Indian ridge were also generated at a ridge segment between two pieces of unusually old crust.

Reduced partial melting of a depleted mantle source has been proposed as a cause of the NaTi basalts in the Woodlark basin [Perfit et al., 1986]. A mid-ocean ridge type, depleted spurce for these rocks is supported by measured $\varepsilon^{\mathrm{Nd}}$ values of +9.2 to +10.0 [Staudigel et al., 1986]. The reduced partial melting of the mantle could be indirectly caused by the increased crustal cooling which is inferred for all three of the tectonic locations of $\mathrm{NaTi}$ basalts mentioned previously. However, if one accepts all of the Cayman trough glasses as $\mathrm{NaTi}$ basalts, the reduced partial melting must occur in the mantle upwelling cell beneath the ridge crest. 


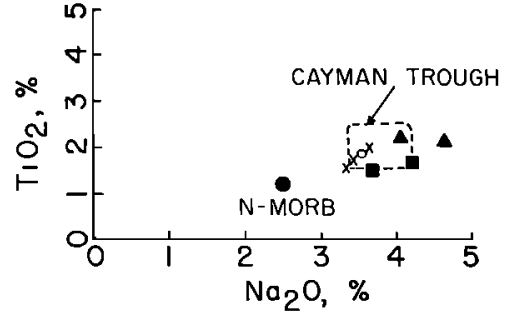

Fig. 9. $\mathrm{TiO}_{2}$ versus $\mathrm{Na}_{2} \mathrm{O}$ content of $\mathrm{NaTi}$ basalt glasses from different areas compared to normal MORB with the same $\mathrm{Mg}$ number. Dotted line: Field of analyses from the Cayman trough. Triangles: Woodlark basin. Crosses: Charlie Gibbs ridge. Squares: Southwest Indian ridge. Open circle: Explorer ridge.

The ridge segment in the Cayman trough is 110 $\mathrm{km}$ long, but conductive cooling of the oceanic crust near transform faults is calculated to extend less than $15 \mathrm{~km}$ from ridge-transform intersections [Forsythe and Wilson, 1984]. However, convective cooling of the upwelling cell in the asthenosphere near transform faults can extend to distances equal to the thickness of the transform lithosphere [Forsythe and Wilson, 1984]. On a ridge segment sandwiched between two transforms with age offsets of $34 \mathrm{~m}$.y., the convection cell beneath an entire 110-km-long ridge segment could be affected. Consequently, the upwelling cell or cells feeding the ridge crest in the Cayman trough upwell more slowly than those beneath more typical ridge segments, thereby producing decreased decompressive melting of their MORB source (Figure 10). However, the age offset on the Simbo transform is only 2.6 m.y., much less than at the Cayman trough transforms, the Charlie Gibbs transforms, and the old Southwest Indian ridge triple junction. If increased cooling causes reduced partial melting of the asthenosphere, some other tectonic factor must act to cause anomalous crustal cooling on the Simbo transform.

Two features of the Woodlark basin could cause anomalous crustal cooling along the Simbo transform: the long duration of subduction in this area could cool the underlying asthenosphere [Perfit et al., 1986] or the additional hydrothermal cracking and cooling induced by lithospheric flexure and transform fault orientation could increase the thickness of the lithosphere at the ridge-transform intersection. The relative importance of these two mechanisms could be tested by drilling for $\mathrm{Na}-\mathrm{Ti}$ basalts at flexural bulges which are covered by over $300 \mathrm{~m}$ of sediment and are unequivocally hydrothermally sealed.

Much of the Explorer plate, located off the coast of southwestern Canada, is covered by over $300 \mathrm{~m}$ of sediment. However, the continental sediment supply to the Explorer rift, a ridge segment within the flexural bulge of the subducting Explorer plate [Riddihough et al., 1980; Cousens et al., 1984], is diverted by the Paul Revere transform ridge (age offset, $4.5 \mathrm{~m}$.y.), which parallels the trench. Thus, the hydrothermal system in the Explorer rift should not be sealed, and flexurally induced cracking and increased cooling cannot be ruled out. One sample from the Explorer rift has a low water content $(0.11 \%)$, an unfractionated $\mathrm{Mg}$ number (61), and a $\mathrm{NaTi}$ basalt composition of $0.28 \% \mathrm{~K}_{2} \mathrm{O}, 3.52 \%$ $\mathrm{Na}_{2} \mathrm{O}$, and $1.82 \% \mathrm{TiO}_{2}$ [Cousens et al., 1984].

The second hypothesis for the origin of $\mathrm{NaTi}$ basalts, increased asthenospheric cooling induced by long term subduction, could also produce $\mathrm{NaTi}$ basalts on the Explorer ridge. However, the cooling induced by long term subduction is not required to remain confined within the flexural bulge and should not be affected by thick sediment cover. Despite extensive recent study of the Gorda-Juan de Fuca-Explorer plate system [Clague et al., 1984; International N.E. Pacific Activities Consortium (INPAC), 1985], we know of no NaTi basalts dredged at locations outside the flexural bulge with thin ridge crest sediment cover or at locations within the flexural bulge with thick ridge crest sediment cover. Therefore, additional asthenospheric cooling caused by lithospheric flexure and/or transform fault orientation is the best explanation for the Woodlark basin and the Explorer ridge NaTi basalts. This increased cooling would cause the Simbo and Paul Revere transforms to behave thermally like much longer transforms and would produce the $\mathrm{NaTi}$ basalts.

\section{VOLATILES AND SEISMICITY WITHIN THE RELICT SUBDUCTED PLATE}

Perfit et al. [1986] suggested that the arclike rocks in the Woodlark basin are caused by volatile addition to the Woodlark basin asthenosphere during the previous phase of subduction to the north (Figure 2). To test this idea, we calculated the length of time that volatiles could be held in stable mineral phases in a descending slab. The mantle retention times of volatiles contained within a subducting plate are a function of the age of the plate at the initiation of subduction, the thickness of the volatile-rich layer, and the breakdown temperatures and pressures of volatile-rich minerals. The maximum thickness of the volatile-rich layer of normal, unflexed oceanic crust is $\sim 8 \mathrm{~km}$ [Abbott and Lyle, 1984]. Once this volatile-rich layer reaches a temperature and/or pressure sufficient to cause either partial melting or complete breakdown of volatile-rich phases, the subducting plate can no longer contribute volatiles to the overlying mantle. The mantle retention time is defined here as the total length of the portion of the subducting slab which retains volatiles divided by the convergence rate.

We have calculated mininum mantle retention 

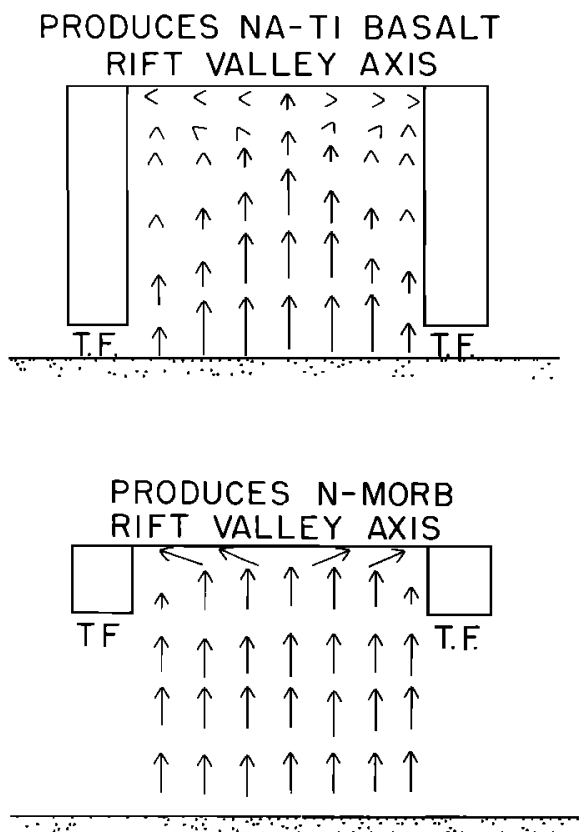

Fig. 10. Schematic cartoons of slowed asthenospheric upwelling beneath the axial valley of a mid-ocean ridge producing NaTi basalts (top) compared to faster asthenospheric upwelling beneath a normal ridge crest producing MORBs (bottom). Boundaries are transform faults (TF). Area inside blocks labeled TF represents the additional lithospheric thickness in the transform fault zones. Dotted area is the zone of partial melt in the asthenosphere. Length of arrows is proportional to the speed of asthenospheric upwelling.

times for volatiles in a subducting plate using the thermal model of McKenzie [1969] and an $8-\mathrm{km}$-thick volatile-rich layer. This thermal model does not include the effects of the thermal gradients in the overlying lithospheric plate, which would increase the retention time. Although the actual retention times are somewhat longer than our calculated values, relative retention times are portrayed quite accurately. Because horizontal heat conduction along the axis of the slab makes an insignificant contribution to reheating of rapidly subducting plates, minimum retention times calculated from this model using convergence rates from 2 to $12 \mathrm{~cm} / \mathrm{yr}$ are convergence-rate-independent to within $1 \%$ for 10 - to $100-$ m.y.-old plates and to within $10 \%$ for 1 - to 10 -m.y.-old plates. The reheating of slabs subducting at less than $2 \mathrm{~cm} / \mathrm{yr}$ is compressed into a relatively small region by the slow convergence, producing large horizontal temperature gradients along the axis of the slab. Because of these large horizontal temperature gradients, horizontal and vertical heat conduction are both important, and volatiles in slowly subducting slabs have shorter mantle residence times than in other plates of the same thermal age. However, these large horizontal temperature gradients will not be present in the deeper portions of a rapidly subducting plate which suddenly ceased convergence. Consequently, we can use a thermal model developed for faster converging plates to predict the thermal behavior of a plate which suddenly ceased convergence.

In order to facilitate observational tests of our model, we have also calculated minimum mantle "retention times" for seismicity within a subducting plate. Seismicity "retention times" depend on the time required to heat the center of the plate to a temperature too high for brittle failure to occur. Although the brittle-to-ductile transition is clearly dependent on strain rates, the transition from seismic to aseismic behavior can be described reasonably accurately by using a cutoff potential temperature of $750^{\circ} \mathrm{C}$ at depths of 0-125 km [Molnar et al., 1979; Jarrard, 1986; Chen and Molnar, 1983; Weins and Stein, 1983]. Because the center of a subducting plate is usually about $100-125 \mathrm{~km}$ beneath the volcanic line of an island arc [Gill, 1981; Jarrard, 1986], seismic activity will not be present beneath the arc if the entire plate is heated above $750^{\circ} \mathrm{C}$.

Volatile retention times in the plate depend on the pressure and temperature of breakdown of volatile-rich minerals and/or initiation of partial melting. The top $8 \mathrm{~km}$ of a subducting plate is usually about $100 \mathrm{~km}$ beneath the arc. At $30 \mathrm{kbar}$ (roughly $100 \mathrm{~km}$ ), partial melting and the breakdown of richterite-tremolite commence at $\sim 1000^{\circ} \mathrm{C}$ [Green, 1973; Hariya and Terada, 1973]. Thus, within a subducting plate which suddenly ceased convergence, the last volatiles in the portion of the plate beneath the volcanic line would be lost at temperatures of $\sim 1000^{\circ} \mathrm{C}$, and the last seismicity at temperatures of $\sim 750^{\circ} \mathrm{C}$.

\section{ORIGIN OF THE ARCLIKE ROCKS}

The volatile and incompatible element enrichments in the arclike lavas from the Woodlark basin have been proposed to be the result of a polarity reversal of the trench-arc system [Perfit et al., 1986] about 8- to 10-m.y. ago [Coleman and Kroenke, 1981; Cooper and Taylor, 1985]. However, the relict slab continued to converge and to produce thrusting on the Solomon island arc until at least 6 m.y. ago [Coleman and Kroenke, 1981]. Thus, the polarity reversal of the arc and subduction of the relict slab ended less than $6 \mathrm{~m}$.y. ago.

The model of Perfit et al. [1986] does not rely upon fluids coming directly from the older, previously subducting slab and entering the island arc magmas, but instead relies upon subduction and associated mantle contamination prior to the polarity 


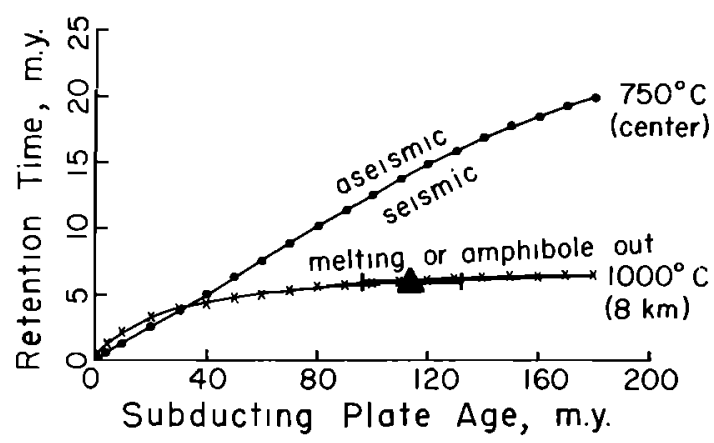

Fig. 11. Minimum mantle retention times of volatiles and seismicity within plates which had different ages at the onset of subduction. Dotted curve: Time needed to warm center of a subducting plate to $750^{\circ} \mathrm{C}$, as a function of subducted plate age. Seismic activity is thought to cease above this temperature. Hachured curve: Time needed to warm the upper $8 \mathrm{~km}$ of the plate above $1000^{\circ} \mathrm{C}$. Most hydrothermally emplaced volatiles will have been lost when the plate reaches this temperature.

Minimum mantle retention times are calculated using the formula in McKenzie [1969]. The triangle with error bars shows the estimated age and time since polarity reversal of the previously subducting Pacific plate which lies beneath the New Georgia arc.

reversal and consequent cessation of subduction. Our simple thermal models (below) indicate that an old, previously subducting plate can remain cold enough to contribute volatiles to the surrounding mantle for millions of years after subduction has ceased. Consequently, the slab which stopped subducting less than $6 \mathrm{~m}$.y. ago could be presently contributing volatiles to the mantle convection cell that feeds the Woodlark basin ridge segment closest to the trench.

The minimum mantle retention times for volatiles and seismicity at depths of 100-125 km show several interesting trends which provide observational tests of our results (Figure 11). Older subducting plates will remain seismically active for a longer time than they retain volatiles. Conversely, younger subducting plates (less than $30 \mathrm{~m}$.y. old upon entering the trench) will retain volatiles for a longer time than they remain seismically active. Volatiles derived from the subducting plate are widely believed to be an important contributor to island arc volcanism [McBirney, 1969; Boettcher, 1973; Nichols and Ringwood, 1973; Kushiro, 1973]. Consequently, these results imply that young, actively subducting plates will sometimes produce active island arcs without the presence of subcrustal seismicity beneath the volcanic line. The Cascades arc and the Andes in southern Chile, which have no seismic activity beneath the volcanic line [Barazangi and Dorman, 1969], are examples of this. In southern Columbia and northern Ecuador, the seismic activity near the volcanoes is shallow and sparse and can be attributed to surface deformation rather than to a subducting plate at depth [Drummond et al., 1981; Kellogg et al., 1985]. The subducting plates in these three areas are all

Pleistocene to Miocene in age [Heezen and Fornari, 1976; Sugi and Uyeda, 1984], consistent with our model predictions.

These models also imply that volatiles could continue to be derived from the old, nonsubducting slab in zones of polarity reversal of the arc. The previously subducting Pacific plate which underlies the New Georgia/Solomon island arcs was of Lower Cretaceous age (100-136 m.y.) at the initiation of subduction [Heezen et al., 1976]. The minimum volatile retention time in a plate of this age is $6 \mathrm{~m} . \mathrm{y}$. (Figure 8). The relict slab ceased subducting less than $6 \mathrm{~m}$.y. ago. Consequently, the incompatible element enrichments in the rocks of the Woodlark basin spreading center may be the result of active volatile and incompatible element loss by an immobile slab of Pacific plate (Figure 2) and are not required to be caused by a previous phase of mantle enrichment.

\section{CONCLUSIONS}

Lithospheric flexure at trenches causes tension in the upper part of the subducting plate, which cracks new rock and forms new fault blocks. Further evidence for flexurally induced cracking is the high 3 He content of pore fluids from DSDP site 436 , located on the crest of the flexural bulge of 110-m.y.-old oceanic crust entering the Japan trench. If the flexed plate is young and has thin sediment cover, the new cracks and increased permeability should also increase the intensity of hydrothermal activity. This increase in hydrothermal activity would be most pronounced on a ridge crest or transform fault sitting on a flexural bulge. Increased ridge crest hydrothermal circulation would lower near-surface isotherms and could cause a deeper magma chamber. A magma chamber located in the uppermost mantle, where basalt magma could react with harzburgite, explains the anomalous high-Mg andesites on Simbo transform fault, which lies within the flexural bulge of the Woodlark trench. The NaTi basalts, also extruded on the Simbo transform, may be the result of eruption through anomalously thick, young oceanic lithosphere. The cold neighboring plates cause mantle upwelling to slow, thus producing decreased decompressive partial melting of the rising asthenosphere. NaTi basalts also occur at short ridge segments sandwiched between long age offset transforms and at large age offset ridge jumps, both of which are logical locations for slowed mantle upwelling due to anomalously cold neighboring lithosphere.

Mathematical models of minimum mantle 
retention times of seismicity and volatiles are consistent with the following observations: (1) active Holocene volcanism and no deep, subarc seismicity in the Cascades, northern Ecuador, southern Colombia, and the southern Andes; and (2) incompatible element enrichment in the rocks of the Woodlark basin spreading center less than 6 m.y. after the relict Pacific plate stopped subducting. Consequently, the incompatible element enrichments in the rocks of the Woodlark basin spreading center are not required to be caused by a previous phase of mantle enrichment but could continue to be derived from the old, previously subducting plate.

The unusual rock types found in the Woodlark basin may also be found in ophiolites emplaced as a result of ridge subduction and/or trench reversal. The Troodos ophiolite, which is postulated to have formed as a result of a combination of ridge subduction and seafloor spreading behind a trench [Moores et al., 1984], has some arclike rocks [Miyashiro, 1973; Robinson et al., 1983]. The NaTi basalts found in the Woodlark basin would be easy to dismiss as spilites and/or altered basalt if they were found in an ophiolite and are not likely to have been reported. Boninites occur in the pillow lavas of the Troodos ophiolite [Cameron et al., 1979; Robinson et al., 1983]. Consequently, two of the unusual rock types reported from the Woodlark basin, the high- $\mathrm{Mg}$ andesites (boninites) and the arclike rocks, are found in an ophiolite emplaced as a result of ridge subduction and trench reversal. The research on the Woodlark basin should be applicable to other ophiolites emplaced during ridge subduction and/or trench reversal.

These models of the effects of lithospheric flexure can be tested by dredging and by heat flow surveys in another area of active ridge subduction. The Woodlark basin is not the optimum location for such a test because of the small amounts of sediment covering the flexural bulge and because of the complicating effects of the polarity reversal of the arc. The requirements for such a test area are 50-200 m of sediment cover in the area of the flexural bulge and a ridge orientation nearly parallel to the trench. The Peru-Chile ridge is most like the Woodlark basin in its orientation to the trench, and it also has sufficient sediment cover $(50-100 \mathrm{~m})$ for a heat flow survey. Furthermore, due to somewhat unusual circumstances, areas with roughly equal sediment cover on the same age of oceanic crust can be found both within and outside the flexural bulge [Cande and Leslie, 1986]. Other areas of active ridge subduction have the wrong sediment distribution and ridge orientation (the Explorer ridge [INPAC, 1985]), are undergoing a ridge jump (the east Pacific rise at $18^{\circ} \mathrm{N}$ [Luhr et al., 1985]), or are perpendicular to the trench axis (Ayu trough [Weissel and Anderson, 1978]).

\section{APPENDIX: CALCULATION OF STRESS AND THE WIDTH OF FLEXURAL BULGE}

At small deflections of the plate, the elastic thickness is approximately equal to the mechanical thickness. This assumption is particularly good for trenches [McNutt, 1984]. Therefore, all of the following calculations are made assuming that the elastic and mechanical thickness are roughly equal. The thickness, $h$, which is equivalent to the depth to the $600^{\circ} \mathrm{C}$ isotherm [McNutt, 1984], is proportional to the square root of the plate age:

$$
h(t)=7.4 \times 10^{-2} \mathrm{t}^{1 / 2} \mathrm{~cm}
$$

where $t$ is the age of the oceanic plate in seconds. The load at the trench causes the plate to deform with the following flexure, $y(x)$ :

$y(x)=\frac{A(t)}{0.067} \cos [k(t) x] \exp [-k(t) x]$

where $k(t)$ is the flexural wavenumber, $x$ is distance from the trench, and $\mathrm{A}(\mathrm{t})$ is the maximum flexure induced by the load (which occurs at $k x=3 \pi / 4$ ) (Figure 3) [Caldwell and Turcotte, 1979]. We estimate $A(t)$ from McNutt's [1984] data:

$\mathrm{A}(\mathrm{t})=5.2 \times 10^{-4} \mathrm{t}^{1 / 2} \mathrm{~cm}$

where $t$ is in seconds. The flexural wavenumber is related ultimately to the plate thickness through the relations:

$k(t)=[\Delta \rho g / 4 D]^{1 / 4}$

where $\Delta \rho$ is the difference in density between seawater and mantle (assumed to be $2.3 \mathrm{gm} / \mathrm{cm}^{3}$ ), g is the acceleration due to gravity, and $\mathrm{D}$ is the plate's flexural rigidity, given by:

$\mathrm{D}=\mathrm{Yh}^{3}(\mathrm{t}) / 12\left(1-\mathrm{v}^{2}\right)$

where $\mathrm{Y}$ is Young's modulus (assumed to be $1.8 \times$ $10^{12}$ dynes $/ \mathrm{cm}^{2}$ ) and $v$ is Poisson's ratio (assumed to be 0.25 ). The flexural wavenumber is therefore:

$k(t)=5.4 \times 10^{-2} \mathrm{t}^{-3 / 8} \mathrm{~cm}^{-1}$ 
The flexure induces stress, $\sigma$, in the lithosphere:

$\sigma=(\lambda+2 \mu) \mathrm{z} \partial^{2} \mathrm{y} / \partial \mathrm{x}^{2}$

where $\lambda$ and $\mu$ are the Lamè constants (assumed $\lambda+2 \mu=2.17 \times 10^{12}$ dynes $/ \mathrm{cm}^{2}$ ) and $\mathrm{z}$ is distance above the plate's neutral surface (that is, middle). The maximum stress, which occurs at $\mathrm{z}=\mathrm{h} / 2$ and $\mathrm{kx}=\pi / 4$ is then:

$\sigma_{\max }=1.16 \mathrm{t}^{1 / 4}$ bars

The stress decreases linearly with depth in the lithosphere, while the strength of the rock increases linearly with depth. Thus the top part of the lithosphere is cracked down to some depth where the stress and strength are equal. Using the Bodine et a1. [1981] estimate of $0.222 \mathrm{bars} / \mathrm{m}$ for the strength, the depth of cracking is:

$d=3.7 \times 10^{-2} t^{1 / 2}\left\{1-\left[14100 \mathrm{t}^{-1 / 4}+1\right]^{-1}\right\} \mathrm{cm}$

Equations 7 and 8 are plotted in figures 4 and 5 .

Acknowledgments. We thank M. Perfit, R. Barnes, B. Taylor, and H. Staudigel for providing us with preprints of their unpublished manuscripts. We thank W. White, W. Menke, S. Hoffman, P. Hoffman, B.Taylor and N.Sleep for their critical comments. Acknowledgment is made to the Donors of the Petroleum Research Fund, administered by the American Chemical Society for the support of Abbott during this research. Fisk was supported by OCE84-12395.

\section{REFERENCES}

Abbott, D. H., and M. Lyle, Age of oceanic plates at subduction and volatile recycling, Geophys. Res. Lett., 11, 951-954, 1984.

Abbott, D. H., W. H. Menke, M. Hobart, and R. $\mathrm{N}$. Anderson, Evidence for excess pore pressures in southwest Indian Ocean sediments, J. Geophys. Res., 86, 813-828, 1981.

Anderson, R. N., M. G. Langseth, and J. G. Sclater, The mechanisms of heat transfer through the floor of the Indian ocean, $\mathbf{I}$. Geophys. Res. 82, 3391-3409, 1977.

Anderson, R. N., M. A. Hobart, and M. G. Langseth, Convective heat transfer in the Indian Ocean, Science, 204, 828-832, 1979.
Anderson, R. N., M. D. Zoback, S. H. Hickman, and R. L. Newmark, Permeability versus depth in the upper oceanic crust: In situ measurements in DSDP hole 504B, eastern equatorial Pacific, J. Geophys. Res., 90, 3659-3669, 1985.

Barazangi, M., and J. Dorman, World seismicity maps compiled from ESSA, Coast and Geodetic Survey, epicenter data, 1961-1967, Bull. Seismol. Soc. Am., 59, 369-380, 1969.

Bodine, J. H., M. S. Steckler, and A. B. Watts, Observations of flexure and the rheology of the oceanic lithosphere, J. Geophys. Res., 86 , 3695-3707, 1981.

Boettcher, A. L., Volcanism and orogenic belts--The origin of andesites, Tectonophysics, 17 , 223-240, 1973.

Bratt, S. R., E. A. Bergman, and S. C. Solomon, Thermoelastic stress: How important as a cause of earthquakes in young oceanic lithosphere?, I. Geophys. Res., 20, 10,249-10,260, 1985.

Byerly, G. R., W. G. Melson, and P. R. Vogt, Rhyodacites, andesites, ferrobasalts, and oceanic tholeiites from the Galapagos spreading center, Earth Planet. Sci. Lett., 30. 215-221, 1976.

Caldwell, J. G., and D. L. Turcotte, Dependence of the thickness of the elastic oceanic lithosphere on age, J. Geophys. Res., 83, 7572-7579, 1979.

Cameron, W. G., E. G. Nisbet, and V. J. Dietrich, Petrographic dissimilarities between ophiolite and ocean floor basalts, in Ophiolites, edited by A. Panayoitou, pp. 182-192, Cyprus Geological Survey Dept., Nicosea, Cyprus, 1979.

Cande, S. C., and R. B. Leslie, Late Cenozoic tectonics of the southern Chile trench, $\underline{\mathbf{J}}$. Geophys. Res., 91, 471-496, 1986.

CAYTROUGH, Geological and geophysical investigation of the mid-Cayman Rise spreading center: Initial results and observations, in Deep Drilling Results in the Atlantic Ocean: Ocean Crust, Maurice Ewing Ser., vol. 2, edited by M. Talwani, C. G. Harrison, and D. E. Hays, pp. 66-93, AGU, Washington, D. C., 1979.

Chen, W. P., and P. Molnar, The depth distribution of intercontinental and intraplate earthquakes and its implications for the thermal and mechanical properties of the lithosphere, J. Geophys. Res., 88, 4183-4214, 1983.

Clague, D. A., W. Friesen, P. Quinterno, M. Holmes, J. Morton, R. Bouse, L. Mortenson, and A. Davis, Preliminary geological, geophysical, and biological data from the Gorda Ridge, U.S. Geol. Surv. Open File Rep. 84-364, 1984.

Cocker, J. D., B. J. Griffin, and K. Muehlenbachs, Oxygen and hydrogen isotope evidence for seawater-hydrothermal alteration of the 
MacQuarie Island ophiolite, Earth Planet. Sci. Lett., 61, 112-122, 1982.

Coleman, P. J., and L. W. Kroenke, Subduction without volcanism in the Solomon islands arc, Geomarine Lett., 1, 129-134, 1981.

Cooper, P. A., and B. Taylor, Polarity reversal in the Solomon Islands arc, Nature, 314, 428-430, 1985.

Cousens, B. L., R. L. Chase, and J. G. Schilling, Basalt geochemistry of the Explorer Ridge area, northeast Pacific Ocean, Can. J. Earth Sci., 21, 157-170, 1984.

Drummond, K. J., G. W. Moore, X. Golovchenko, R. L. Larson, W. C. Pitman, III, W. A. Rinehart, T. Simkin, and L. Siebert, Plate tectonic map of the circum-Pacific region, northeast quadrant, Circum-Pac. Counc. for Energy and Miner. Resour., Am. Assoc. of Pet. Geol., Tulsa, Okla., 1981.

Embley, R. W., M. A. Hobart, R. N. Anderson, and $\mathrm{D}$. Abbott, Anomalous heat flow in the northwest Atlantic: A case for continued hydrothermal circulation in 80-m.y. crust, $\mathrm{J}$. Geophys. Res., 88, 1067-1074, 1983.

Fehn, U., K. E. Green, R. P. Von Herzen, and L. $M$. Cathles, Numerical models for the hydrothermal field at the Galapagos spreading center, I. Geophys. Res., 88, 1033-1048, 1983.

Fisk, M. R., Basalt interaction with harzburgite and the formation of high-Mg andesites, Geophys. Res. Lett., 13, 467-470, 1986.

Forsythe, D.W., and B. Wilson, Three-dimensional temperature structure of a ridge-transform-ridge system, Earth Planet. Sci. Lett., 70, 355-362, 1984.

Fox, P. J., and D. G. Gallo, A tectonic model for ridge-transform-ridge plate boundaries: Implications for the structure of the oceanic lithosphere, Tectonophysics, 104, 205-242, 1984.

Fujita, K., and N. H. Sleep, Membrane stresses near mid-ocean ridge-transform boundaries intersections, Tectonophysics, 50, 207-221, 1978.

Gill, J., Orogenic Andesites and Plate Tectonics, $390 \mathrm{pp}$., Springer-Verlag, New York, 1981.

Green, D. H., Experimental melting studies on a model upper mantle composition at high pressure under water-saturated and water-undersaturated conditions, Earth Planet. Sci. Lett., 19, 37-53, 1973.

Gregory, R. T. and H. P. Taylor, An oxygen isotope profile in a section of Cretaceous oceanic crust Samail ophiolite, Oman: Evidence for $\partial \mathrm{O}^{18}$ buffering of the oceans by deep ( $>5 \mathrm{~km}$ ) seawater-hydrothermal circulation at mid-ocean ridges, J. Geophys. Res, 86, 2737-2755, 1981.

Hariya, Y., and S. Terada, Stability of richterite $_{50}$ tremolite $_{50}$ solid solution at high pressures and possible presence of sodium calcic amphibole under upper mantle conditions, Earth Planet. Sci. Lett., 18, 72-76, 1973.

Hart, S. R., K, Rb, Cs, Sr, and Ba contents and $\mathrm{Sr}$ isotope ratios of ocean floor basalts, Philos. Trans. R. Soc. London, Ser. A., 268, 573-587, 1971.

Heezen, B. C., and D. J. Fornari, Pacific Ocean map, in Atlas Geologique du Monde, UNESCO, Paris, 1976.

Hickey, R. L., and F. A. Frey, Geochemical characteristics of boninite series volcanics: Implications for their source, Geochim. Cosmochim. Acta, 46, 2099-2115, 1982.

Hobart, M. A., M. G. Langseth, and R. N. Anderson, A geothermal and geophysical survey on the south flank of the Costa Rica rift: Sites 504 and 505, Init. Repts. Deep Sea Drill. Proj., $83,379-404,1985$.

INPAC, Workshop report on drilling in the N.E. Pacific, Univ. of Wash., Seattle, 1985.

Jarrard, R. D., Relations among subduction parameters, Rev. Geophys. 24, 217-284, 1986.

Johnson, R. W., R. P. Macnab, R. J. Arculus, R. J. Ryburn, R. J. S. Cooke, and B. W. Chappell, Bamus volcano, Papua New Guinea: Dormant neighbor of Ulawan, and magnesian-andesite locality, Geol. Rundsch., 72, 207-237, 1983.

Johnson, R. W., A. L. Jacques, C. H. Langmuir, M. R. Perfit, H. Staudigel, P. N. Dunkley, B. W. Chappell, and S. R. Taylor, Igneous petrology and geochemistry of volcanic-rock dredge samples from the New Georgia forearc area: The magmatic effects of ridge subduction, in Marine Geology. Geophysics, and Geochemistry of the Woodlark Basin-Solomon Islands Region. Circum-Pac. Counc. for Energy and Miner. Resour., Earth Sci. Ser., in press, 1986.

Kellogg, J. N., I. J. Ogujiofor, and D. R. Kansakar, Cenozoic tectonics of the Panama and North Andes blocks, in Memoirs of the Sixth Latin American Congress on Geology, vol. I, edited by J. Valdiri Wagner, pp. 40-59, Consejo Consultivo de Directores de Servicios Geologicos de Latinoamerica y el Caribe, Bogota, Columbia, 1985.

Kushiro, I., Origin of some magmas in oceanic and circum-oceanic regions, Tectonophysics, 17 , 211-222, 1973.

Lewis, B. T. R., Evolution of ocean crust seismic velocities, Annu. Rev. Earth Planet. Sci. 6 , 377-404, 1978.

Lister, C. R. B., On the penetration of water into hot rock, Geophys. J. R. Astron. Soc., 39, 465-509, 1974.

Lister, C. R. B., The basic physics of water 
penetration into hot rock, in Hydrothermal Processes at Seafloor Spreading Centers, edited by P. A. Rona, K. Bostrom, L. Laubier, and K. L. Smith, Jr., pp. 141-168, Plenum, New York, 1983.

Luhr, J. F., S. A. Nelson, J. F. Allan, and I. S. E. Carmichael, Active rifting in southwestern Mexico: Manifestations of an incipient eastward spreading-ridge jump, Geology, 13, 54-75, 1985.

Lupton $_{s}$ J. E., and H. Craig, Excess ${ }^{3} \mathrm{He}$ in oceanic basalts: Evidence for terrestrial primordial helium, Earth Planet. Sci. Lett., 26, 133, 1975.

Lupton, J. E., G. P. Klinkhammer, W. L. Normark, R. Haymon, K. C. MacDonald, R. F. Weiss, and $\mathrm{H}$. Craig, Helium-3 and manganese at the $21^{\circ} \mathrm{N}$ East Pacific Rise hydrothermal site, Earth Planet. Sci. Lett., 50 , 115-127, 1980.

Martin, R. J., III, Time-dependent crack growth in quartz and its application to the creep of rocks, J. Geophys. Res., 77, 1406-1419, 1972.

McBirney, A. R., Compositional variations in calc-alkaline suites of Central America, in Proceedings of the Andesite Conference, Bull. Oreg. Dep. Geol. Miner. Ind. 65, 185-189, 1969.

McKenzie, D. P., Speculations on the causes and consequences of plate motions, Geophys. J. R. Astron. Soc., 18, 1-32, 1969.

McNutt, M. K., Lithospheric flexure and thermal anomalies, J. Geophys. Res., 89, 11,18011,194, 1984.

Miyashiro, A., The Troodos ophiolite was probably formed in an island arc, Earth Planet. Sci. Lett. 19, 218-224, 1973.

Molnar, P., D. Freeman, and J. Shih, Lengths of intermediate and deep seismic zones and temperatures in downgoing slabs of lithosphere, Geophys. J. R. Astron. Soc., 43, 763-774, 1979.

Moores, E. M., and E. D. Jackson, Ophiolites and oceanic crust, Nature, 250, 136-139, 1974.

Moores, E. M., P. T. Robinson, J. Malpas, and C. Xenophonotos, Model for the origin of the Troodos massif, Cyprus, and other mideast ophiolites, Geology, 12, 500-503, 1984.

Nichols, I. A., and A. E. Ringwood, Effect of water on olivine stability in tholeiites and the production of silica-saturated magmas in the island-arc environment, J. Geol., 81, 285-300, 1973.

Parsons, B. A., and J. G. Sclater, An analysis of the variation of ocean floor bathymetry and heat flow with age, J. Geophys. Res., 82, 803-827, 1977.

Perfit, M. R., C.H. Langmuir, M. Baekisapa, B. Chappell, R. W. Johnson, H. Staudigel, and S. R. Taylor, Geochemistry of volcanic rocks from the Woodlark Basin: Addressing the questions of ridge subduction and a reversal in the polarity of subduction, in Marine Geology. Geophysics. and Geochemistry of the Woodlark BasinSolomon Islands Region, Circum-Pac. Counc. for Energy and Miner. Resour., Earth Sci. Ser., in press, 1986.

Reagan, M. K., and A. Meijer, Geology and geochemistry of early arc-volcanic rocks from Guam, Geol. Soc. Am. Bull., 25, 701-713, 1984.

Richardson, R. M., S. C. Solomon, and N. H. Sleep, Tectonic stress in the plates, Rev. Geophys., 17, 981-1019, 1979.

Riddihough, R. P., R. G. Currie, and R. D. Hyndman, The Dellwood knolls and their role in triple junction tectonics off northern Vancouver Island, Can. J. Earth Sci., 17, 577-593, 1980.

Robinson, P. T., W. G. Melson, T. O'Hearn, and H. U. Schmincke, Volcanic glass compositions of the Troodos ophiolite, Cyprus, Geology, 11, 400-404, 1983.

Schilling, J. G., M. Zajac, R. Evans, T. Johnson, W. White, J. D. Devine, and R. Kingsley, Petrologic and geochemical variations along the Mid-Atlantic Ridge from $29^{\circ} \mathrm{N}$ to $73^{\circ} \mathrm{N}$, Am. J. Sci., 283, 510-586, 1983.

Sclater, J. G., R. L. Fisher, P. Patriat, C. Tapscott, and B. Parsons, Geophys. J. R. Astron. Soc., 64, 587-604, 1981.

Schweller, W. J., and L. D. Kulm, Extensional rupture of oceanic crust in the Chile trench, Mar. Geol., 28, 271-291, 1978.

Schweller, W. J., L. D. Kulm, and R. A. Prince, Tectonics, structure, and sedimentary framework of the Peru-Chile Trench, Mem. Geol. Soc. Am., 154, 323-350, 1981.

Searle, R. C., The active part of the Charlie Gibbs fracture zone: A study using sonar and other geophysical techniques, J. Geophys. Res., 86, 243-262, 1981.

Staudigel, H., M. McCulloch, A. Zindler, and M. Perfit, Complex ridge subduction and island arc magmatism: An isotopic study of the New Georgia forearc and the Woodlark basin, in Marine Geology, Geophysics, and Geochemistry of the Woodlark Basin-Solomon Islands Region. Circum-Pac. Counc. for Energy and Miner. Resour., Earth Sci. Ser., in press, 1986.

Stefanson, V., Physical environment of hydrothermal systems in Iceland and on submerged oceanic ridges, in Hydrothermal Processes at Seafloor Spreading_Centers, edited by P. A. Rona, K. Bostrom, L. Laubier, and K. L. Smith, Jr., pp. 321-360, Plenum, New York, 1983.

Sugi, N., and S. Uyeda, Subduction of young oceanic plates without deep focus earthquakes, Bull. Soc. Geol. Fr, 26, 245-254, 1984.

Taylor, B., A geophysical survey of the 
Woodlark-Solomons region, in Marine Geology. Geophysics. and Geochemistry of the Woodlark Basin-Solomon Islands Region. Circum-Pac. Counc. for Energy and Miner. Resour., Earth Sci. Ser., in press, 1986.

Taylor, B., and N. F. Exon, An investigation of ridge subduction in the Woodlark-Solomons region: Introduction and background, in Marine Geology. Geophysics, and Geochemistry of the Woodlark Basin-Solomon Islands Region. Circum-Pac. Counc. for Energy and Miner. Resour., Earth Sci. Ser., in press, 1986.

Verhoogen, J., F. J. Turner, L. E. Weiss, C. Wahrhaftig, and W. S. Fyfe, The Earth, 748 pp., Holt, Rinehart, and Winston, New York, 1970.

Von Huene, R., and J. Aubouin, Summary-Leg 67, Middle America Trench transect off Guatemala, Init. Repts. Deep Sea Drill. Proj., 67, 775-793, 1982.

Watts, A. B., J. H. Bodine, and M. S. Steckler, Observations of flexure and state of stress in the oceanic lithosphere, J. Geophys. Res., 85 , 6369-6376, 1980.

Weins, D. A., and S. Stein, Age dependence of oceanic intraplate seismicity and implications for lithospheric evolution, J. Geophys. Res., 88, 6455-6468, 1983.

Weissel, J. K., and R. N. Anderson, Is there a Caroline plate?, Earth Planet. Sci. Lett., 41, 143-158, 1978.

Weissel, J. K., B. Taylor, and G. D. Karner, The opening of the Woodlark basin, subduction of the Woodlark spreading system, and the evolution of northern Melanesia since Mid-Pliocene time, Tectonophysics, 87 , 253-277, 1982.

D. Abbott and M. Fisk, College of Oceanography, Oregon State University, Corvallis, OR, 97331 .

(Received June 23, 1986;

revised August 11, 1986;

accepted August 11, 1986.) 